\title{
Mid-Term Comparative Outcomes of Both In Situ and Anatomically Reduced Hips of Slipped Capital Femoral Epiphysis
}

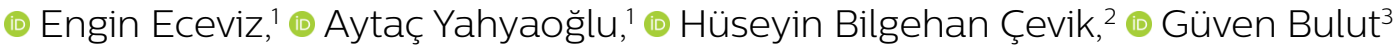

\author{
'Department of Orthopaedics and \\ Traumatology, University of Health \\ Sciences, Kartal Dr. Lütfi Kırdar City \\ Hospital, İstanbul, Turkey \\ ${ }^{2}$ Department of Orthopaedics and \\ Traumatology, University of Health \\ Sciences, Dışkapı Yıldırım Beyazıt \\ Research and Training Hospital, \\ Ankara, Turkey \\ ${ }^{3}$ Department of Orthopaedics and \\ Traumatology, University of Health \\ Sciences, Sancaktepe Şehit Prof. Dr \\ Illhan Varank Training and Research \\ Hospital, İstanbul, Turkey \\ Submitted: 17.08.2020 \\ Accepted: 20.08.2020 \\ Correspondence: \\ Hüseyin Bilgehan Çevik \\ SBÜ, Dışkapı Yıldııım Beyazıt \\ Eğitim ve Araştırma Hastanesi, \\ Ortopedi ve Travmatoloji Kliniği, \\ Ankara, Turkey \\ E-mail: bilgehancevik@gmail.com
}

Keywords: Capital femoral
epiphysis; slippage;
slipped; SCFE.
cc) (P)
Attribution-NonCommercial 4.0 International License.

\begin{abstract}
Objective: Most of the previous studies have shown good functional outcomes for most patients after in situ pinning or pinning with anatomical reduction of slipped capital femoral epiphyses (SCFE). We undertook a retrospective study to document comparative outcomes of both treated groups of 25 SCFE patients.
\end{abstract}

Methods: Between 2005 and 2013, 21 patients (26 hips) with SCFE underwent in situ pinning or pinning with anatomical reduction at a tertiary referral center. Medical records and radiographs were reviewed for slip characteristics. Magnetic resonance imaging (MRI) was performed to all patients at final visits. Mean follow-up was 139 months (range, 64 to 179).

Results: There was no significant difference between in situ group and reduction group regarding range of motion (ROM), Visual Analog Scale (VAS), and Harris Hip Score (HHS) of hip ( $p>0.05$ ). Mean outcome scores were; HHS 80.4, and VAS 2.9 respectively.

Conclusion: Especially in the anatomic reduction group, a decrease in hip ROM was observed (not statistically significant) compared to the in situ group. MRI revealed atrophy of the peri-hip musculature in the reduction group. This present study may suggest that patients with SCFE whether anatomically reduced or in situ pinned may not contribute to clinical outcomes.

\section{INTRODUCTION}

Slipped capital femoral epiphysis (SCFE) is defined as the displacement of the proximal femoral epiphysis back and down relative to the metaphysis. It is one of the relatively common hip disorders especially seen in adolescents. It is more common among obese adolescents. ${ }^{[1]}$ Bilateral SCFE has been reported in the literature between $20-80 \%$. [2] Endocrine pathologies, genetic factors and mechanical factors such as trauma, obesity, inflammatory diseases, chronic renal failure, hypothyroidism and hypopituitarism may be involved in the etiology of the disease. ${ }^{[3]}$

SCFE may cause pain in the hip, groin, knee and thigh medial at the presentation. Physical examination shows a narrowing in range of motion (ROM) of hip, especially internal rotation. One of the most important physical examination finding is the decreased internal rotation of the hip when the hip is passively flexed and externally rotated. The patient should be treated in the early period in order to prevent epiphyseal slipping. ${ }^{[3]}$ SCFE is clinically classified as acute, chronic and acute on the chronic, stable and unstable, and mild-moderate-severe according to the degree of radiological slipping. [4] The aims of the treatment of SCFE are stopping the instant slippage, preventing further slippage and providing stable fixation. Treatment options included closed reduction and spica cast application, fixation with screw or wire (in situ or after reduction), fixation of the slippage by creating a safe dislocation and corrective osteotomies. Serious long 
term complications such as avascular necrosis, limitation in movement, secondary osteoarthritis and chondrolysis may develop after treatment. ${ }^{[5]}$

It is known fact that there were some changes in hip anatomy before the surgical intervention, include acetabular cartilage deformity, femoral acetabular impingement (FAI). However, these changes may not clearly explain ROM changes. The reason of that may be the anatomical reduction of slippage does not treat the capsular fibrosis. Capsular fibrosis is probably present before the surgical management and may not recover after anatomical reduction of slippage.

We undertook a retrospective study to compare the midterm outcomes of hips treated for SCFE with anatomical reduction and pinning, and in situ pinning. We hypothesized that patients with anatomical reduction for SCFE would be at significant risk for limited ROM.

\section{MATERIALS AND METHODS}

A retrospective review was made of all cases of SCFE treated in our clinic between January I, 2005 and December 31,2013 . The study was approved by the local institutional review board. The Department of Orthopaedics database was used to identify all cases of SCFE diagnosed during the study period. All patients presented with radiographic evidence of displacement of the proximal femoral epiphysis back and down relative to the metaphysis. Inclusion criteria were new diagnosis of SCFE treated with in situ pinning or pinning with attempts to reduction. All patients were treated with one or two cannulated screw. Patients with $<5$ years of follow-up, treated with wire were excluded from the study. Over the study period, 34 patients who met the inclusion and exclusion criteria were treated for SCFE. Four patients had undergone initial treatment with osteotomy. Six had $<2$ years of follow-up. Three moved to another city and refuse to final follow-up examination. Thus, final evaluation was made of $2 \mathrm{I}$ patients ( 26 hips). The total $2 \mathrm{I}$ patients comprised 19 male and 2 female, with a mean age of 13.4 years. The detailed distributions of demographic features are given in Table I. Mean time to clinical and radiographic follow-up was 139 months (range, 64 to 179).

Patient files were retrospectively reviewed for demographic features, symptoms and findings at presentation, clinical outcomes, and additional surgery. The information about presentation (acute, acute-on-chronic, chronic) and stability (stable or unstable) of the slippage were noted. [6] The classification of slippage presentation: acute $<3$ weeks, acute-on-chronic as cases of prodromal symptoms before the acute slippage, and chronic $>3$ weeks. Measurements were done by 2 independent orthopaedic surgeons. All patients were invited to final clinical and radiological evaluation. All the patients were also evaluated by magnetic resonance imaging (MRI) for chondrolysis, avascular necrosis, capsular fibrosis and any pathological change.

Table I. Demographical features of patients

\begin{tabular}{|c|c|c|c|c|c|c|}
\hline Patients & Age & Side & Gender & Follow-up (months) & Body mass index & Surgery \\
\hline I & $14-16$ & Bilateral & $M$ & $76(\mathrm{~L})-94(\mathrm{R})$ & $25-26$ & In situ \\
\hline 2 & $10-11$ & Bilateral & $M$ & $64(\mathrm{R})-8 \mathrm{I}(\mathrm{L})$ & $27-35$ & In situ / red \\
\hline 3 & 14 & $\mathrm{R}$ & $M$ & 68 & 30 & In situ \\
\hline 4 & 13 & $\mathrm{~L}$ & $M$ & 146 & 28 & In situ \\
\hline 5 & 13 & $\mathrm{R}$ & $M$ & 147 & 32 & In situ \\
\hline 6 & $12-13$ & Bilateral & $M$ & $148(\mathrm{~L})-153(\mathrm{R})$ & $25-25$ & In situ / red \\
\hline 7 & 16 & L & $M$ & 155 & 32 & In situ \\
\hline 8 & 12 & $\mathrm{~L}$ & $M$ & 155 & 27 & In situ \\
\hline 9 & 13 & $\mathrm{~L}$ & $M$ & 159 & 26 & In situ \\
\hline 10 & II & $\mathrm{L}$ & M & 164 & 21 & In situ \\
\hline 11 & 12 & $\mathrm{~L}$ & $M$ & 178 & 26 & In situ \\
\hline 12 & $14-16$ & Bilateral & $M$ & $151(\mathrm{~L})-179(\mathrm{R})$ & $27-27$ & In situ / red \\
\hline 13 & 13 & L & $M$ & 148 & 30 & In situ \\
\hline 14 & 12 & $\mathrm{R}$ & $\mathrm{F}$ & 172 & 28 & Red \\
\hline 15 & 13 & $\mathrm{R}$ & $M$ & 80 & 27 & Red \\
\hline 16 & 15 & $\mathrm{~L}$ & $M$ & 150 & 29 & Red \\
\hline 17 & 13 & $\mathrm{~L}$ & $M$ & 160 & 26 & Red \\
\hline 18 & 15 & $\mathrm{R}$ & $M$ & 153 & 26 & Red \\
\hline 19 & 13 & $\mathrm{R}$ & $M$ & 159 & 28 & Red \\
\hline 20 & 13 & $\mathrm{~L}$ & $\mathrm{~F}$ & 166 & 30 & Red \\
\hline 21 & $11-14$ & Bilateral & $M$ & $142(\mathrm{~L})-172(\mathrm{R})$ & $29-29$ & Red / red \\
\hline $\begin{array}{l}21 \text { patients, } \\
26 \text { hips }\end{array}$ & $\begin{array}{l}\text { Mean } \pm \text { SD: } \\
13.2 \pm 1.6\end{array}$ & $\begin{array}{c}5 \text { bilateral, } \\
10 \mathrm{~L}, 6 \mathrm{R}\end{array}$ & $19 \mathrm{~F}, 2 \mathrm{M}$ & $\begin{array}{c}\text { Mean } \pm \text { SD: } \\
139.3 \pm 36.3 \text { months }\end{array}$ & $\begin{array}{c}\text { Mean } \pm \text { SD: } \\
27.4 \pm 2.4\end{array}$ & 14 in situ/ 2 red \\
\hline
\end{tabular}



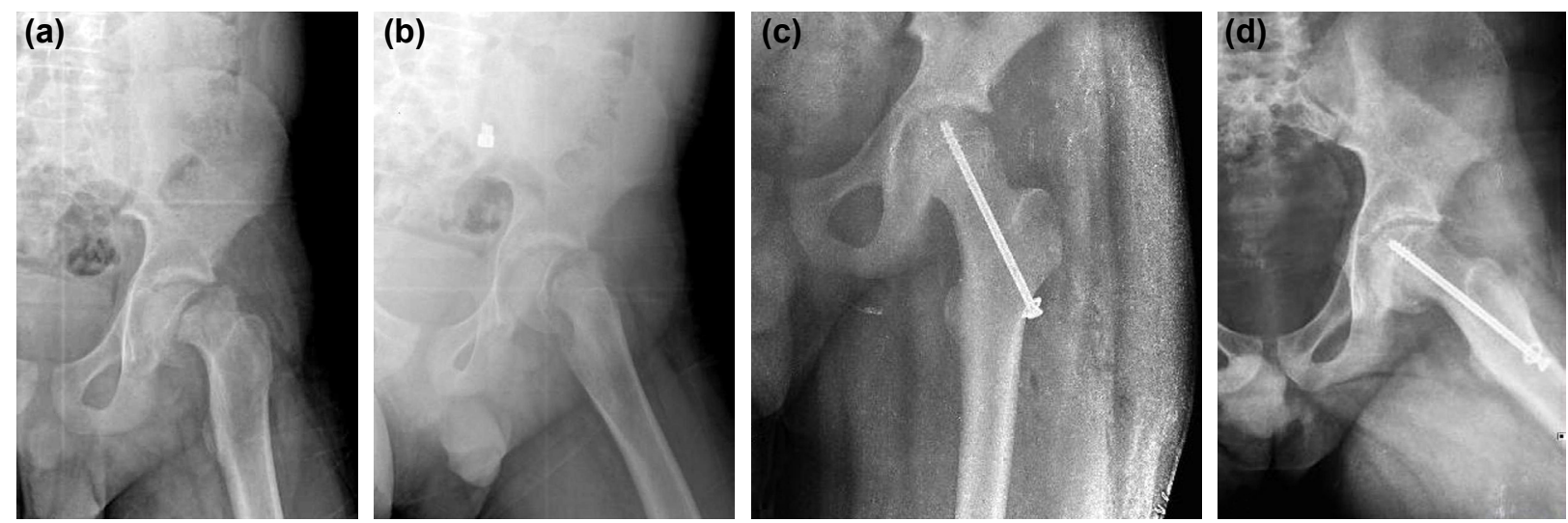

Figure 1. A 13 years old male patient (patient 4) with left hip pain for 5 months. (a, b) Preoperative AP and lateral X-ray films show SCFE. (c, d) Postoperative AP and lateral X-ray films show in situ single-screw fixation.
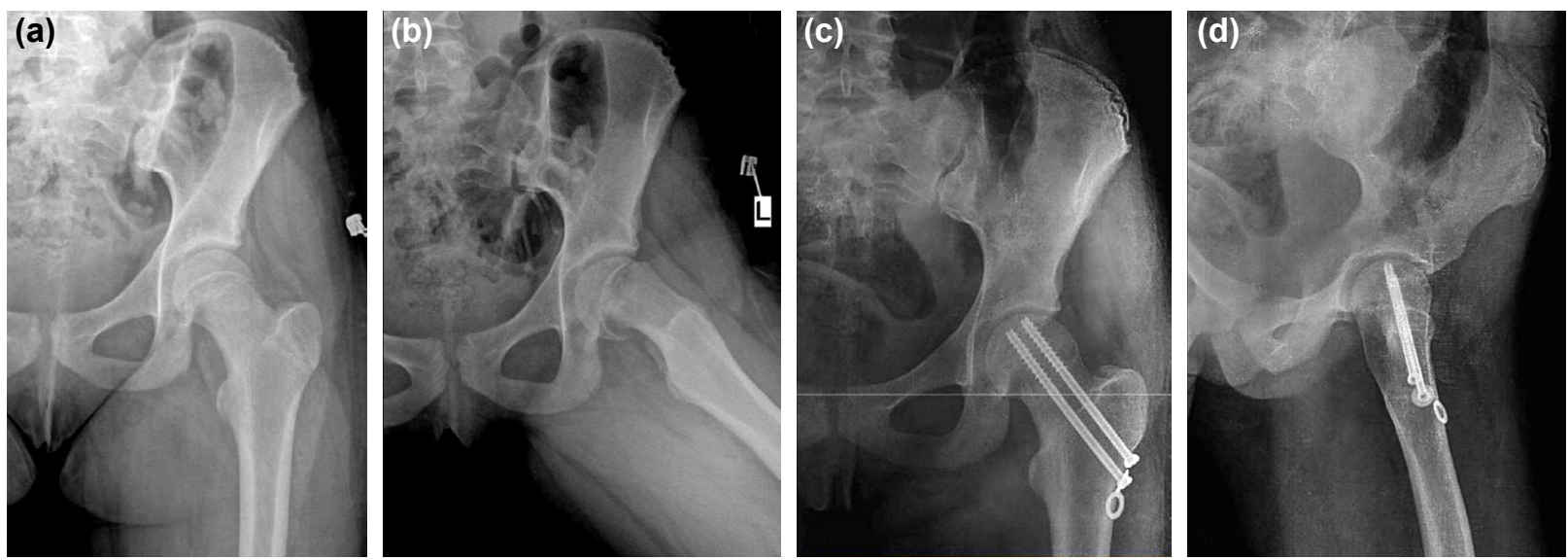

Figure 2. A 13 years old female patient (patient 20) with left hip pain for 15 months. (a, b) Preoperative AP and lateral X-ray films show SCFE. (c, d) Postoperative AP and lateral X-ray films show anatomically reduced slippage with two-screw fixation.

Functional outcomes were evaluated with Harris Hip Score $(\mathrm{HHS}){ }^{[7]}$ The HHS score gives a maximum of 100 points which is subdivided into pain, function, ROM, and deformity. Also, visual analog scale (VAS) was used to measure hip pain on scale of 0 to 10 .

\section{Surgical technique}

The surgical technique was standard for all patients. All the patients were placed in a supine position on a radiolucent table. In reduction group, the surgeon applied manual gentle traction, slight abduction and internal rotation to obtain epiphyseal slipping reduction. Under fluoroscopic assistance, a guide wire inserted to centering to the epiphysis. A small incision was made for guide wire port. A $6.5 \mathrm{~mm}$ diameter cannulated screw of appropriate length was then inserted over the guide wire with fluoroscopic guidance to avoid joint penetration and to make sure the screw was in the center of the epiphysis both on the AP and lateral views. The screw was advanced until all threads engage the epiphysis.

Postoperatively, all patients were allowed immediate toe touch weight-bearing with crutches, regardless of the method of fixation for the first 6 weeks. After the sixth week, weight-bearing was gradually increased within a total of 12 weeks, and full weight-bearing was allowed after the $18^{\text {th }}$ week post surgery. The clinical and radiological evaluations were performed immediately postoperatively, then at $3,6,12$ months, and every year postoperatively. The screws

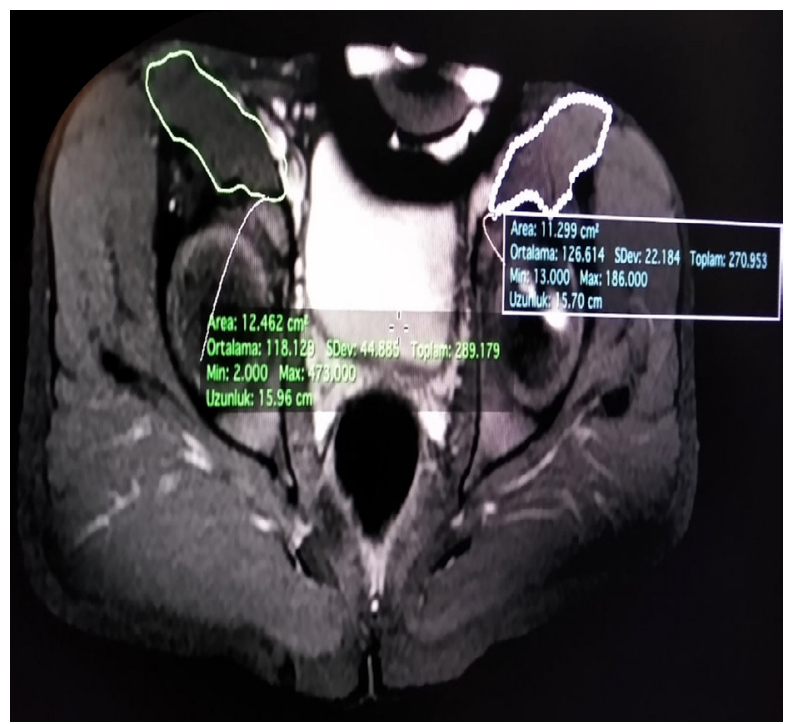

Figure 3. A 15 years old male patient (patient 16) with left SCFE that treated with two-screw fixation after anatomic reduction. Axial MRI show peri-hip musculature atrophy on left hip. 
were removed after epiphyseal closure had occurred. There were no surgery related complications and revisional surgeries were not required in any patient in any patient during the study period.

\section{RESULTS}

Mean body mass index was $27.4 \mathrm{~kg} / \mathrm{m}^{2}$ (range, 2 I to $32 \mathrm{~kg}$ ) $\mathrm{m}^{2}$ ) at the time of diagnosis. There were only 5 patients with $\mathrm{BMI} \geq 30 \mathrm{~kg} / \mathrm{m}^{2}$ (obese). One patient had hypothyroidism at the time of diagnosis. Four slippages were unstable, 22 were stable. One slippage was acute, 2 were acute on chronic, and 23 were chronic. Patients' mean slip angles (angle between shaft and perpendicular to physis per Southwick $)^{[8]}$ were $36^{\circ}\left(15^{\circ}-75^{\circ}\right)$. Of the 26 hips, 14 were pinned in situ and 12 were pinned after anatomical reduction. The measurements of range of motion summarized in Table 2. The mean VAS score was 2.9 , and $31 \%$ $(n=8)$ of patients reported VAS score more than 3 . The mean HHS of all patients was 80.4 (range, 70-86).

Radiographies showed epiphyseal closure and condensed mineral density of the femoral head in all cases, without increasing Southwick angle and without any change in femoral head shape. The MRls showed capsular fibrosis and edema in all the anatomically reduced hips. However, while there was no capsular fibrosis and edema in the in situ group, there was peri-hip muscle atrophy. There was no statistically difference between in situ group and reduction group behalf of range of motion, VAS score, and HHS of hip ( $p>0.05)$.

Of the 26 hips, I developed avascular necrosis and required reconstructive surgery with osteotomy. There was no chondrolysis and limb length discrepancy were develpoed in any patient.

\section{DISCUSSION}

Reduction of slippage procedures had been gain popularity among pediatric orthopaedic surgeons..$^{[9,10]}$ In this present study, there were no statistical difference in clinical outcomes between both anatomically reduced and in situ pinned groups.

This study provides clinical and radiological outcomes of two group of patients after both in situ pinning and anatomically reduced hips of SCFE at a mean of 139 months postoperatively.
The SCFE managed with in situ pinning has previously been presented acceptable with good long-term outcomes in literature. ${ }^{[1,12]}$ But the authors demonstrated that there was high rate of pistol-grip deformity which related to osteoarthritis (OA) in early adulthood. ${ }^{[1]}$ The patients which were adolescents might expect that they have normal hip functions rather than acceptable. ${ }^{[13]}$ Ziebarth et al. $^{[14]}$ declared that $89 \%$ of SCFE patients had acetabular cartilage damage at the time of the slippage, even they said that there was no relationship between slippage angle and severity of acetabular cartilage damage. SCFE engenders cam deformity of hip that leads to change the normal biomechanics of the hip resulting in impingement type pain. [15] The degree of remodeling, and why some patients with severe slippage do functionally well following in situ pinning are not fully understood yet. It is believed that the limitation of ROM had similar pathophysiology with FAI. ${ }^{[13]}$ It might expected that anatomically reduced hips would have better ROM than in situ pinned hips. ${ }^{[16]}$ However, there was no statistically significant difference in ROM between both in situ pinned hips and anatomically reduced hips in this study. We tried to answer the question; why a more anatomical femoral head had similar clinical outcomes with the non-anatomical ones. In the present study, all patients undergone to magnetic resonance imaging (MRI) of hips. The MRIs showed capsular fibrosis and edema in anatomically reduced hips. On the other hand, while there was no capsular fibrosis and edema in the in situ group, there was only peri-hip muscle atrophy. But peri-hip musculature atrophy does not explain the lack of difference between the clinical outcomes of two groups.

There are various limitations associated with this study. In general, pediatric population, this entity has a low incidence, thus the small sample size is another limitation of study. In this study patients who were followed for a mean of 139 months and $20 \%$ of patients, did not evaluated because of missing data. The limited follow up may have caused them to appear small numbers of potential complications like AVN, chondrolysis, and the need for additional surgery. Another limitation is the absence of randomization according to chronicity and stability in the both groups.

In conclusion, It is suggested via the current study that patients with SCFE, whether anatomically reduced or in situ pinned, do not alter the prognosis of patients in terms of clinical outcomes. The prospective studies with large numbered patients and longer follow-up periods are needed to achieve more meaningful results.

Table 2. Clinical and radiological parameters of patients (mean $\pm S D$ )

\begin{tabular}{lcccccc}
\hline & Southwick angle & Flexion & Internal rotation & External rotation & HHS & VAS \\
\hline In situ & $32^{\circ}( \pm \mid 7.5)$ & $108.6^{\circ}( \pm 8.7)$ & $22.1^{\circ}( \pm 7.5)$ & $30.4^{\circ}( \pm 9.1)$ & $80( \pm 6.8)$ & $2.9( \pm 1.3)$ \\
Anatomical reduction & $40.1^{\circ}( \pm I I .9)$ & $107.1^{\circ}( \pm I I .4)$ & $20^{\circ}( \pm 7.7)$ & $29.6^{\circ}( \pm 8.7)$ & $80.4( \pm 6.5)$ & $3.1( \pm 1.2)$ \\
All & $36^{\circ}( \pm 15.6)$ & $107.9^{\circ}( \pm 9.8)$ & $21.2^{\circ}( \pm 7.5)$ & $30^{\circ}( \pm 8.7)$ & $80.8( \pm 6.5)$ & $3( \pm 1.2)$ \\
& $\mathrm{p}>0.05$ & $\mathrm{p}>0.05$ & $\mathrm{p}>0.05$ & $\mathrm{p}>0.05$ & $\mathrm{p}>0.05$ & $\mathrm{p}>0.05$ \\
\hline
\end{tabular}

SD: Standard deviation; HHS: Harris Hip Score; VAS: Visual analog scale. 
Ethics Committee Approval

Approved by the Kartal Dr. Lütfi Kırdar Training and Research Hospital Local Ethics Committee (No: 2019/5/4/164/I, Date: 30/10/2019).

Informed Consent

Retrospective study.

Peer-review

Internally peer-reviewed.

Funding Sources

No external funding was received in support of this work. Authorship Contributions

Concept: E.E., H.B.Ç., A.Y.; Design: H.B.Ç., A.Y.; Supervision: H.B.Ç., E.E., G.B.; Materials: H.B.Ç., A.Y.; Data: H.B.Ç., A.Y.; Analysis: E.E., H.B.Ç., A.Y.; Literature search: E.E., H.B.Ç., A.Y., G.B.; Writing: H.B.Ç., E.E.; Critical revision: E.E., H.B.Ç., A.Y., G.B.

Conflict of Interest

None declared.

\section{REFERENCES}

1. Manoff EM, Banffy MB, Winell JJ. Relationship between Body Mass Index and slipped capital femoral epiphysis. J Pediatr Orthop 2005;25:744-6. [CrossRef]

2. Phillips PM, Phadnis J, Willoughby R, Hunt L. Posterior sloping angle as a predictor of contralateral slip in slipped capital femoral epiphysis. J Bone Joint Surg Am 2013;95:146-50. [CrossRef]

3. Hellmich HJ, Krieg AH. Slipped capital femoral epiphysis-etiology and pathogenesis. Orthopade 2019;48:644-50. [Article in German].

4. Bittersohl D, Bittersohl B, Westhoff B, Krauspe R. Slipped capital femoral epiphysis: clinical presentation, diagnostic procedure and clas- sification. Orthopade 2019;48:651-8. [Article in German]. [CrossRef]

5. Guzzanti V, Falciglia F, Stanitski CL. Slipped capital femoral epiphysis in skeletally immature patients. J Bone Joint Surg Br 2004;86:731-6.

6. Loder RT, Richards BS, Shapiro PS, Reznick LR, Aronson DD. Acute slipped capital femoral epiphysis: the importance of physeal stability. J Bone Joint Surg Am 1993;75:1134-40. [CrossRef]

7. Harris WH. Traumatic arthritis of the hip after dislocation and acetabular fractures: treatment by mold arthroplasty. An end-result study using a new method of result evaluation. J Bone Joint Surg Am 1969;51:737-55. [CrossRef]

8. Southwick WO. Osteotomy through the lesser trochanter for slipped capital femoral epiphysis. J Bone Joint Surg Am 1967;49:807-35.

9. Ziebarth K, Steppacher SD, Siebenrock KA. The modified Dunn procedure to treat severe slipped capital femoral epiphysis. Orthopade 2019;48:668-76. [Article in German]. [CrossRef]

10. Otani T, Kawaguchi Y, Marumo K. Diagnosis and treatment of slipped capital femoral epiphysis: Recent trends to note. J Orthop Sci 2018;23:220-8. [CrossRef]

11. Castañeda P, Ponce C, Villareal G, Vidal C. The natural history of osteoarthritis after a slipped capital femoral epiphysis/the pistol grip deformity. J Pediatr Orthop 2013;33:S76-82. [CrossRef]

12. Boyer DW, Mickelson MR, Ponseti IV. Slipped capital femoral epiphysis. Long-term follow-up study of one hundred and twenty-one patients. J Bone Joint Surg Am 1981;63:85-95. [CrossRef]

13. Bond EC, Phillips P, Larsen PD, Hunt L, Willoughby R. Long-term hip function in slipped capital femoral epiphysis treated with in situ pinning. J Orthop Surg (Hong Kong) 2019;27:2309499018822234.

14. Ziebarth K, Leunig M, Slongo T, Kim YJ, Ganz R. Slipped capital femoral epiphysis: relevant pathophysiological findings with open surgery. Clin Orthop Relat Res 2013;471:2156-62. [CrossRef]

15. Bloomfield MR, Erickson JA, McCarthy JC, Mont MA, Mulkey P, Peters CL, et al. Hip pain in the young, active patient: surgical strategies. Instr Course Lect 2014;63:159-76.

16. Zilkens C, Bittersohl B, Jäger M, Miese F, Schultz J, Kircher J, et al. Significance of clinical and radiographic findings in young adults after slipped capital femoral epiphysis. Int Orthop 2011;35:1295-301.

\section{In Situ ve Anatomik Redükte Edilmiş Femur Başı Epifiz Kayması Olan Kalçaların Orta Dönem Karşılaştırmalı Sonuçları}

Amaç: Femur başı epifiz kayması (FBEK) tedavisinde in situ pinleme ve anatomik redüksiyon sonrası pinlemenin çoğu hastada iyi fonksiyonel sonuçlar verdiği önceki çalışmalarda göstermiştir. Bu çalışmada her iki tedavi yöntemi ile tedavi edilen 25 FBEK hastalarının sonuçlarını geriye dönük ve karşılaşıırmalı olarak incelemeyi amaçladık.

Gereç ve Yöntem: Üçüncü basamak bir hastanede 2005-20I3 yılları arasında FBEK'li 2 I hastaya (26 kalça) in situ pinleme veya anatomik redüksiyon uygulanana hastalar çalışmaya dahil edildi. Tıbbi kayıtlar ve radyografiler FBEK özellikleri açısından incelendi. Son poliklinik kontrollerinde tüm hastalara manyetik rezonans görüntülemeleri (MRG) yapıldı. Ortalama takip süresi I39 aydı (dağıım, 64-I79).

Bulgular: In situ pinleme ile anatomik redüksiyonla beraber pinleme grupları arasında eklem hareket açıklı̆ı (EHA), Visual Analog Skalası (VAS) ve Harris Kalça Skoru (HKS) arasında anlamlı bir fark yoktu ( $p>0.05)$. Ortalama sonuçlar HHS için 80.4 ve VAS için 2.9 olarak bulundu.

Sonuç: Özellikle anatomik redüksiyon grubunda, in situ gruba göre kalça EHA'sında bir azalma gözlendi (istatistiksel olarak anlamlı değil). Manyetik rezonans görüntüleme anatomik redüksiyon grubunda kalça çevresi kaslarında atrofi olduğunu ortaya çıkardı. Bu çalışma, FBEK'li hastaların anatomik redüksiyon sonrası veya in situ pinleme ile tedavi edilmesinin, klinik sonuçlara bir etkisinin olmayabileceği öne sürülebilir.

Anahtar Sözcükler: Epifiz kayması; FBEK; femur başı; kayma. 